Division of Geological \& Geophysical Surveys

RAW-DATA FILE 2016-8

\title{
U-PB ZIRCON AGE DATA FROM META-IGNEOUS ROCKS IN THE CLEARWATER MOUNTAINS, MOUNT HAYES A-6 QUADRANGLE, ALASKA
}

\author{
by
}

Evan Twelker and Paul O'Sullivan

$\$ 3.00$

May 2016

THIS REPORT HAS NOT BEEN REVIEWED FOR TECHNICAL CONTENT OR

FOR CONFORMITY TO THE EDITORIAL STANDARDS OF DGGS

\author{
Released by \\ STATE OF ALASKA \\ DEPARTMENT OF NATURAL RESOURCES \\ Division of Geological \& Geophysical Surveys \\ 3354 College Road \\ Fairbanks, Alaska 99709-3707
}





\section{TABLE OF CONTENTS}

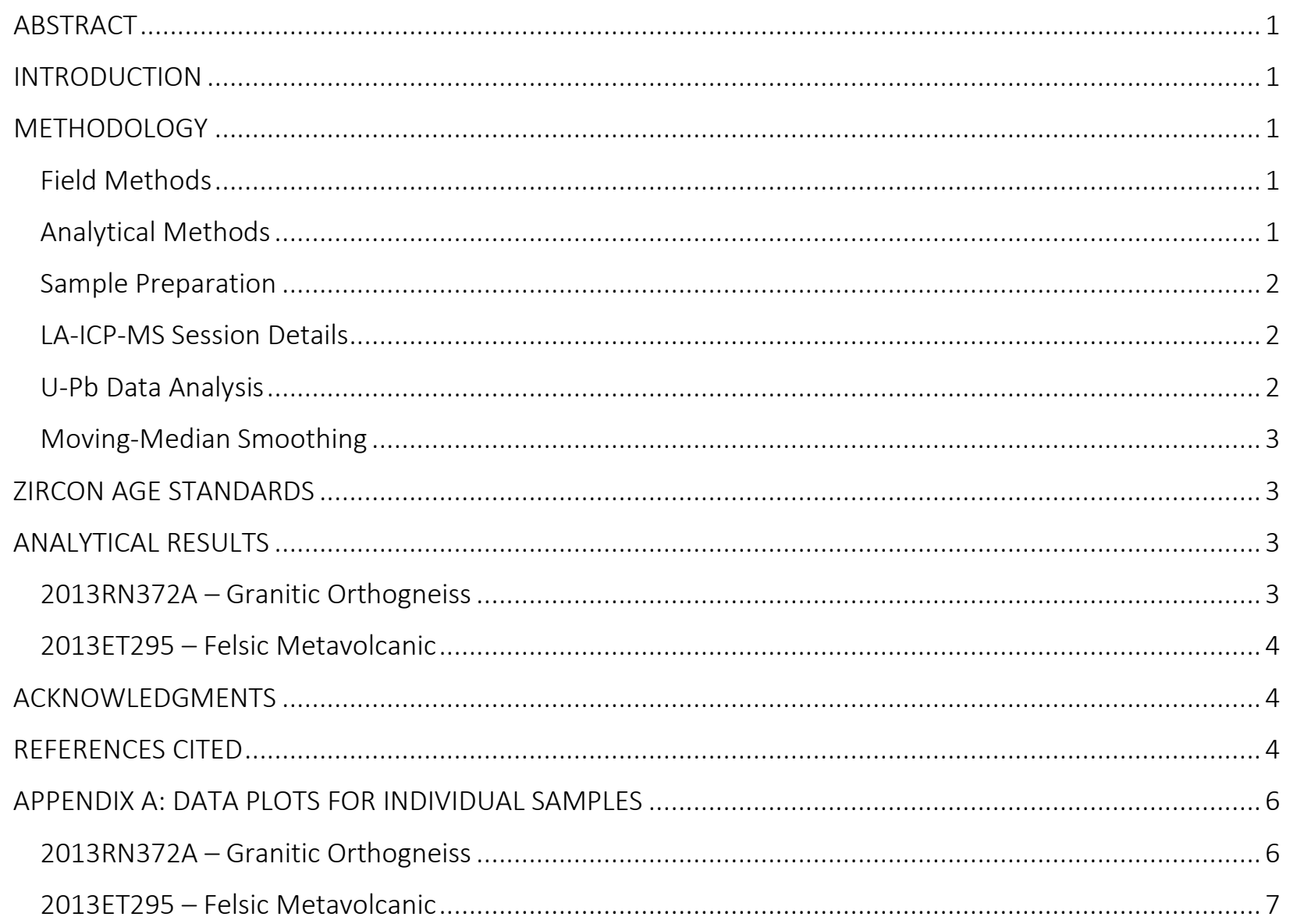




\title{
U-PB ZIRCON AGE DATA FROM META-IGNEOUS ROCKS IN THE CLEARWATER MOUNTAINS, MOUNT HAYES A-6 QUADRANGLE, ALASKA
}

\author{
by \\ Evan Twelker ${ }^{1}$, Paul O’Sullivan ${ }^{2}$
}

\begin{abstract}
We report U-Pb zircon geochronology results for one metavolcanic and one metaplutonic rock sample from the Mount Hayes A- 6 Quadrangle of central Alaska. These samples are representative of rock units assigned to the Clearwater terrane of Jones and others (1987), a sequence of greenschist-grade metavolcanic and metasedimentary rocks of poorly constrained age and tectonic origin. Our results indicate a crystallization age of $277.33 \pm 11.84 \mathrm{Ma}$ for a felsic metavolcanic rock, and a $268.05 \pm 11.64 \mathrm{Ma}$ crystallization age for a granitic metaplutonic unit intruding the former.
\end{abstract}

\section{INTRODUCTION}

From 2013 to 2015 the Alaska Division of Geological \& Geophysical Surveys (DGGS) conducted a multi-year mineral assessment and geological mapping initiative to better understand the geologic context of mineralization hosted by rocks of the western Wrangellia terrane, including magmatic $\mathrm{Ni}-\mathrm{Cu}-\mathrm{Co}-\mathrm{PGE}$, basalt-hosted $\mathrm{Cu}$, and intrusion-related mineralization in the western portion of the Wrangellia terrane. This assessment program consisted of a new geophysical survey (Burns and others, 2014), and reanalysis of archived stream sediment pulps (Werdon and others, 2014), and targeted geological mapping.

The metamorphic rocks of the Clearwater terrane (Jones and others, 1987) form an alleged tectonostratigraphic terrane approximately 2 by $10 \mathrm{~km}$ in extent in the northwestern corner of the Mount Hayes A-6 Quadrangle. Based on limited fossil evidence, the terrane has been variously interpreted as a structurally-bound fragment of a Late Triassic volcanic arc (Clautice and others, 1989, Nokleberg and others, 1992) or potentially a window into middle to late Paleozoic metamorphic basement underlying Wrangellia.

We applied U-Pb zircon geochronology to two samples of meta-igneous rocks to resolve the uncertainty surrounding the precise age and regional correlations of this terrane. The samples were submitted to the Apatite to Zircon, Inc. laboratory (A2Z), where U-Pb age analysis was performed by Paul O'Sullivan in 2014. The resulting data, excerpted from the laboratory report, are presented in this publication. All files can be downloaded from the DGGS website (doi:10.14509/29663).

\section{METHODOLOGY}

\section{Field Methods}

DGGS field geologists collected rock samples from the ground surface; care was taken to collect fresh, unweathered samples representative of rock types in the map area. Locations were recorded using handheld GPS units with an estimated horizontal accuracy of approximately $10 \mathrm{~m}$. Location coordinates for all dated samples are provided in an accompanying .csv file in decimal degree format, WGS84 datum. This file also contains brief descriptions of each sample based on field observations.

\section{Analytical Methods}

DGGS submitted selected rock samples to Apatite to Zircon, Inc., in 2014. Paul O'Sullivan directed the processing and analyses of the samples in the A2Z laboratory. Laser ablation-inductively coupled plasma-mass spectrometry (LA-ICP-MS) analyses were performed at the A2Z laboratory, in Viola, Idaho. Detailed discussion of laboratory techniques is provided below.

\footnotetext{
${ }^{1}$ Alaska Division of Geological \& Geophysical Surveys, 3354 College Road, Fairbanks AK 99709-3707; evan.twelker@alaska.gov

2 GeoSep Services, 1521 Pine Cone Road Moscow, ID 83843
} 


\section{Sample Preparation}

Zircon grains were isolated and prepared for Laser Ablation-Inductively Coupled Plasma-Mass Spectrometry (LA-ICP-MS) analysis using standard procedures combined with specific customized procedures described by Donelick and others (2005). Whole rock samples were crushed using a jaw crusher with the minimum jaw separation set to 2-3 mm, sieved through 300 $\mu \mathrm{m}$ nylon mesh, and the $<300 \mu \mathrm{m}$ size fraction washed with tap water and allowed to dry at room temperature. Zircon was separated from other mineral species using a combination of lithium metatungstate (density $\sim 2.9 \mathrm{~g} / \mathrm{cm}^{3}$ ), Frantz magnetic separator, diiodomethane (density $\left.\sim 3.3 \mathrm{~g} / \mathrm{cm}^{3}\right)$, and hand-panning separation procedures. Epoxy wafers $(\sim 1 \mathrm{~cm} \times 1 \mathrm{~cm}) \mathrm{con}$ taining zircon grains for LA-ICP-MS were polished manually using $3.0 \mu \mathrm{m}$ and $0.3 \mu \mathrm{m} \mathrm{Al}_{2} \mathrm{O}_{3}$ slurries to expose internal zircon grain surfaces. The polished zircon grain surfaces were washed in $5.5 \mathrm{M} \mathrm{HNO}_{3}$ for $20 \mathrm{~s}$ at $21^{\circ} \mathrm{C}$ prior to introduction into the laser system sample cell.

\section{LA-ICP-MS Session Details}

LA-ICP-MS data collection was performed at the A2Z laboratory in Viola, Idaho. Individual zircon grains were targeted for data collection using a Resonetics RESOlution M-50 $193 \mathrm{~nm}$ solid-state laser ablation system using a $20 \mu \mathrm{m}$ diameter laser spot size, $5 \mathrm{~Hz}$ laser firing rate, and ultra-high purity He as the carrier gas. Isotopic analyses of the ablated zircon material were performed using an Agilent 7700x quadrapole mass spectrometer using high purity Ar as the plasma gas. The following masses (in amu) were monitored for 0.005 s each in pulse detection mode: 202, 204, 206, 207, 208, 232, 235, and 238. At time $=0.0 \mathrm{~s}$, the mass spectrometer began monitoring signal intensities; at time $=6.0 \mathrm{~s}$, the laser began ablating zircon material; at time $=20.0 \mathrm{~s}$, the laser was turned off and the mass spectrometer stopped monitoring signal intensities. A total of 30 data scans were collected for each zircon spot analyzed, comprising approximately four background scans, approximately four transition scans between background and background+signal, and approximately 22 background+signal scans.

\section{U-Pb Data Analysis}

Previous LA-ICP-MS studies of U-Pb zircon dating used the so-called intercept method, which assumes that isotopic ratio varies linearly with scan number due solely to linearly varying isotopic fractionation (Chang and others, 2006; Gehrels and others, 2008). The data modeling approach favored here was the modeling of background-corrected signal intensities for each isotope at each scan. Background intensity for each isotope was calculated using a fitted line (for decreasing background intensity) or using the arithmetic mean (for non-decreasing background intensity) at the global minimum of selected isotopes ( ${ }^{206} \mathrm{~Pb},{ }^{232} \mathrm{Th}$, and ${ }^{238} \mathrm{U}$ ) for the spot. Background+signal intensity for each isotope at each scan was calculated using the median of fitted ( $2^{\text {nd }}$ order polynomial) intensity values for a moving window (7 scans wide here) that includes the scan. The precision of each background-corrected signal intensity value was calculated from the precision of background intensity value and the precision of the background+signal intensity value.

Zircon U-Pb age standards used during analysis are summarized in the table below, including the 1,099 $\pm 0.6 \mathrm{Ma}$ FC zircon (FC1 of Paces and Miller, 1993) used here as the primary age standard. Isotopic data for FC were used to calculate Pb/U fractionation factors and their absolute errors for each FC data scan at each FC spot; these fractionation factors were smoothed session-wide for each data scan using the median of fitted ( $1^{\text {st }}$-order polynomial) fractionation factor values for a moving window (11 FC spots wide here) that includes the current FC spot and scan. Under the operating conditions of the LA-ICP-MS sessions in this study, fractionation factors were found to vary strongly with scan number, decreasing with increasing scan number (presumably due to increasing ablation pit depth and the effect this had on fractionation, (for example, Paton and others, 2010). The zircon crystal lattice is widely known to accumulate $\alpha$-radiation damage (for example, Zhang and others, 2009, and references therein). It was assumed here that increased $\alpha$-damage in a zircon leads to a decrease in the hardness of the zircon; this in turn leads to a faster rate of laser penetration into the zircon during ablation, leading to dependence of isotopic fractionation on the degree of zircon lattice radiation damage. Ages calculated for all zircon age standards, when those standards were treated as unknowns, were used to construct a fractionation factor correction curve (exponential form) in terms of accumulated radiation damage. The notion of matrix-matched zircon standard and zircon unknown has been proposed largely on the basis of trace-element chemistry (for example, Black and others, 2004). In this study, time and lattice damage, parameters that are invisible to instruments used to characterize trace-element chemistry, were introduced and applied based on measured $\mathrm{U}$ and Th chemistries to effectively matrix-match standard and unknown zircons. 
Uranium decay constants and the ${ }^{238} \mathrm{U} / 235 \mathrm{U}$ isotopic ratio reported in Steiger and Jäger (1977) were used in this study. Errors for the isotopic ratios ${ }^{207} \mathrm{~Pb} /{ }^{235} \mathrm{U}_{\mathrm{c}}\left({ }^{235} \mathrm{U}_{\mathrm{c}}=137.88^{238} \mathrm{U}\right),{ }^{206} \mathrm{~Pb} /{ }^{238} \mathrm{U}$, and ${ }^{207} \mathrm{~Pb} /{ }^{206} \mathrm{~Pb}$ at each scan included errors from the background-corrected signal values for each isotope, the fractionation factor error, and an additional relative error term required to force 95 percent of the FC ages to be concordant. Ages for the ratios ${ }^{207} \mathrm{~Pb} /{ }^{235} \mathrm{U}_{\mathrm{c}},{ }^{206} \mathrm{~Pb} /{ }^{238} \mathrm{U}$, and ${ }^{207} \mathrm{~Pb} /{ }^{206} \mathrm{~Pb}$ were calculated for each data scan and checked for concordance; concordance here was defined as overlap of all three ages at the $1 \sigma$ level (the use of $2 \sigma$ level was found to skew the results to include scans with any significant common $\mathrm{Pb}$ ). If the number of concordant data scans for a spot was greater than zero, the more precise age from the concordant-scan-weighted ratio ${ }^{207} \mathrm{~Pb} /{ }^{235} \mathrm{U}_{\mathrm{c}}$, ${ }^{206} \mathrm{~Pb} /{ }^{238} \mathrm{U}$, or ${ }^{207} \mathrm{~Pb} /{ }^{206} \mathrm{~Pb}$ was chosen as the preferred age. Asymmetrical negative-direction and positive-direction age errors were calculated by subtracting and adding, respectively, the isotopic ratio errors in the appropriate age equation (Chew and Donelick, 2012).

\section{Moving-Median Smoothing}

Moving-median smoothing (MMS) is applied here to a subset (window) of $N$ data points $x, y$ of width $m$ values of $x$ to which a polynomial of order $n$ is fitted. For each value of $x$ at each position of the data window, a value of $y$ is calculated for the fitted polynomial. The window is positioned with the right-hand boundary at the left-hand $x$ value and then shifted $N$ - 1 times until the left-hand boundary of the window is positioned at the right-hand $x$ value. At each $x$ position, $m$ fitted values of $y$ are calculated and the median of these fitted values is taken.

\section{ZIRCON AGE STANDARDS}

\begin{tabular}{|c|c|c|c|}
\hline Standard & Standard & U-Pb age $( \pm 2 \sigma)$ & Reference \\
\hline FC & Duluth complex & $1,099.0 \pm 0.6 \mathrm{Ma}$ & Paces and Miller, 1993 \\
\hline F5 & Duluth complex & $\begin{array}{c}1,099.0 \pm 0.6 \mathrm{Ma} \\
\text { (assumed equal to FC- } \\
\text { 1) }\end{array}$ & Paces and Miller, 1993 \\
\hline IF & Fish Canyon Tuff & $28.201 \pm 0.012 \mathrm{Ma}$ & $\begin{array}{l}\text { Lanphere and Baadsraard, 2001; Kuiper and } \\
\text { others, } 2008\end{array}$ \\
\hline MD & Mount Dromedary & $99.12 \pm 0.14 \mathrm{Ma}$ & Renne and others, 1998 \\
\hline PX & Peixe & $563.5 \pm 1.6 \mathrm{Ma}$ & Gehrels and others, 2008 \\
\hline R3 & Braintree complex & $418.9 \pm 0.4 \mathrm{Ma}$ & Black and others, 2004 \\
\hline $\mathrm{T} 2$ & $\begin{array}{l}\text { Temora 2, Middledale gabbroic } \\
\text { diorite }\end{array}$ & $416.78 \pm 0.33 \mathrm{Ma}$ & Black and others, 2004 \\
\hline TR & Tardree Rhyolite & $61.23 \pm 0.11 \mathrm{Ma}$ & Dave Chew, pers. commun. \\
\hline
\end{tabular}

\section{ANALYTICAL RESULTS}

Two rock samples were analyzed as part of this study. Data plots for each sample are provided in Appendix A and complete analytical data are included as .csv files in the digital data portion of the report.

\section{RN372A - Granitic Orthogneiss}

This sample of granitic orthogneiss is part of an approximately $1 \mathrm{~km}^{2}$ metamorphosed and variably altered composite stock encompassing units MzPzg, MzPzqd, and MzPzif of Clautice and others (1989) or corresponding unit grs3 of Nokleberg and others (1992). Clautice and others (1989) note field evidence that MzPzg intrudes metavolcanic units ct and ctg. Results of 27 successfully dated zircon grains from this sample range from 229 to $308 \mathrm{Ma}$. A smaller population of less precise ages at 285308 Ma may reflect inheritance from Skolai arc magmatism, which occurred between 290 and 320 Ma (Beard and Barker, 1989). Discounting these grains and other analyses with greater than 10 percent error yields a 13-grain weighted-mean age of $268.05 \pm 11.64 \mathrm{Ma}$. 


\section{ET295 - Felsic Metavolcanic}

This sample is of schistose, porphyritic felsic metavolcanic representative of unit ct of Clautice and others (1989) or unit csv of Nokleberg and others (1992). This unit comprises the major part of the Clearwater terrane (Jones and others, 1987). At map scale, this lithology is interbedded with lesser metasedimentary and metacarbonate rocks of poorly constrained middle to Upper Paleozoic age (Clautice and others, 1989). U-Pb zircon results show a single population with a middle Permian weightedmean age of $\mathbf{2 7 7 . 3 3} \mathbf{\pm} \mathbf{1 1 . 8 4} \mathbf{M a}$ based on 35 of 45 grains analyzed.

\section{ACKNOWLEDGMENTS}

This project was supported by State of Alaska Capital Improvement Project funds through the Strategic and Critical Minerals Assessment program (part of the Airborne Geological/Geophysical Mineral Inventory [AGGMI]). Ray and Margaret Donelick (A2Z) provided technical assistance with sample preparation and LA-ICP-MS data collection.

\section{REFERENCES CITED}

Beard, J.S., and Barker, Fred, 1989, Petrology and tectonic significance of gabbros, tonalites, shoshonites, and anorthosites in a late Paleozoic arc-root complex in the Wrangellia terrane, southern Alaska: The Journal of Geology, v. 97, no. 6, p. 667683. doi:10.1086/629351

Black, L.P., Kamo, S.L., Allen, C.M., Davis, D.W., Aleinikoff, J.N., Valley, J.W., Mundil, Roland, Campbell, I.H., Korsch, R.J., Williams, I.S., and Foudoulis, Chris, 2004, Improved ${ }^{206} \mathrm{~Pb} /{ }^{238} \mathrm{U}$ microprobe geochronology by the monitoring of trace-elementrelated matrix effect; SHRIMP, ID-TIMS, ELA-ICP-MS and oxygen isotope documentation for a series of zircon standards: Chemical Geology, v. 205, no. 1-2, p. 115-140. doi:10.1016/j.chemgeo.2004.01.003

Burns, L.E., CGG, and Fugro GeoServices, Inc., 2014, Wrangellia survey area-Airborne magnetic and electromagnetic data in line (point), grid, vector, and map formats, Talkeetna Mountains, Healy, and Mt. Hayes quadrangles, south-central Alaska: Alaska Division of Geological \& Geophysical Surveys Geophysical Report 2014-1, 56 sheets, scale 1:63,360, 1 DVD. doi:10.14509/27022

Chang, Zhaoshan, Vervoort, J.D., McClelland, W.C., and Knaack, Charles, 2006, U-Pb dating of zircon by LA-ICP-MS: Geochemistry, Geophysics, Geosystems, American Geophysical Union, v. 7, no. 5, 14 p. doi:10.1029/2005GC001100

Chew, D.M., and Donelick, R.A., 2012, Combined apatite fission track and U-Pb dating by LA-ICP-MS and its application in apatite provenance analysis: Mineralogical Association of Canada Short Course, v. 42, p. 219-247. https://www.tcd.ie/Geology/ staff/chewd/publications/chap-12.pdf

Clautice, K.H., Smith, T.E., Pessel, G.H., and Solie, D.N., 1989, Geology and mineral occurrences, upper Clearwater Creek area, Mt. Hayes A-6 Quadrangle, Alaska: Alaska Division of Geological \& Geophysical Surveys Public Data File 89-18, 14 p., 2 sheets, scale 1:24,000. doi:10.14509/1421

Donelick, R.A, O'Sullivan, P.B., and Ketcham, R.A., 2005, Apatite fission-track analysis: Reviews in Mineralogy and Geochemistry, Mineralogical Society of America, v. 58, no. 1, p. 49-94. doi: $\underline{10.2138 / \mathrm{rmg} .2005 .58 .3}$

Gehrels, G.E., Valencia, V.A., and Ruiz, Joaquin, 2008, Enhanced precision, accuracy, efficiency, and spatial resolution of U-Pb ages by laser ablation-multicollector-inductively coupled plasma-mass spectrometry: Geochemistry, Geophysics, Geosystems, American Geophysical Union, v. 9, no. 3, Q03017, 13 p. doi:10.1029/2007GC001805

Jones, D.L., Silberling, N.J., Coney, P.J., and Plafker, George, 1987, Lithotectonic terrane map of Alaska (west of the 141st meridian): U.S. Geological Survey Miscellaneous Field Studies Map 1874-A, 1 sheet, scale 1:2,500,000.

Kuiper, K.F., Deino, A., Hilgen, P.J., Krijgsman, W., Renne, P.R., and Wijbrans, J.R., 2008, Synchronizing rock clocks of Earth history: Science, v. 320, no. 5875, p. 500-504. doi:10.1126/science.1154339

Lanphere, M.A., and Baadsraard, H., 2001, Precise K-Ar, ${ }^{40} \mathrm{Ar} /{ }^{39} \mathrm{Ar}$, Rb-Sr and U-Pb mineral ages from the 27.5 Ma Fish Canyon Tuff reference standard: Chemical Geology, v. 175, no. 3-4, p. 653-671. doi:10.1016/S0009-2541(00)00291-6 
Nokleberg, W.J., Aleinikoff, J.N., Lange, I.M., Silva, S.R., Miyaoka, R.T., Schwab, C.E., and Zehner, R.E., 1992, Preliminary geologic map of the Mount Hayes Quadrangle, eastern Alaska Range, Alaska: U.S. Geological Survey Open-File Report 92-594, 39 p., 1 sheet, scale 1:250,000.

Paces, J.B., and Miller, J.D., Jr., 1993, Precise U-Pb ages of Duluth Complex and related mafic intrusions, northeastern Minnesota-Geochronological insights to physical, petrogenetic, paleomagnetic, and tectonomagnetic processes associated with the 1.1 Ga Midcontinent Rift System: Journal of Geophysical Research, v. 98, no. B8, p. 13,997-14,013. doi:10.1029/93JB01159

Paton, Chad, Woodhead, J.D., Hellstrom, J.C., Hergt, J.M., Greig, Alan, and Maas, Roland, 2010, Improved laser ablation U-Pb zircon geochronology through robust downhole fractionation correction: Geochemistry, Geophysics, Geosystems, v. 11, no. 3, Q0AA06, 36 p. doi:10.1029/2009GC002618

Renne, P.R., Swisher, C.C., Deino, A.L., Karner, D.B., Owens, T.L., and DePaolo, D.J., 1998, Intercalibration of standards, absolute ages and uncertainties in ${ }^{40} \mathrm{Ar} /{ }^{39} \mathrm{Ar}$ dating: Chemical Geology, v. 145, no. 1-2, p. 117-152. doi:10.1016/S00092541(97)00159-9

Steiger, R.H., and Jäger, E., 1977, Subcommission on geochronology-Convention on the use of decay constants in geo- and cosmochronology: Earth and Planetary Science Letters, v. 36, no. 3, p. 359-362. doi:10.1016/0012-821X(77)90060-7

Werdon, M.B., Azain, J.S., and Granitto, Matthew, 2014, Reanalysis of historical U.S. Geological Survey sediment samples for geochemical data from the western part of the Wrangellia terrane, Anchorage, Gulkana, Healy, Mt. Hayes, Nabesna, and Talkeetna Mountains quadrangles, Alaska: Alaska Division of Geological \& Geophysical Surveys Raw Data File 2014-5, 6 p. doi:10.14509/27287

Zhang, Ming, Ewing, R.C., Boatner, L.A., Salje, E.K.H., Weber, W.J., Daniel, Philippe, Zhang, Yanwen, and Farnan, lan, 2009, Pb+ irradiation of synthetic zircon $\left(\mathrm{ZrSiO}_{4}\right)$ - Infrared spectroscopic investigation-Reply: American Mineralogist, v. 94, p. 856858. doi:10.2138/am.2009.542 


\section{APPENDIX A: DATA PLOTS FOR INDIVIDUAL SAMPLES}

2013RN372A - Granitic Orthogneiss
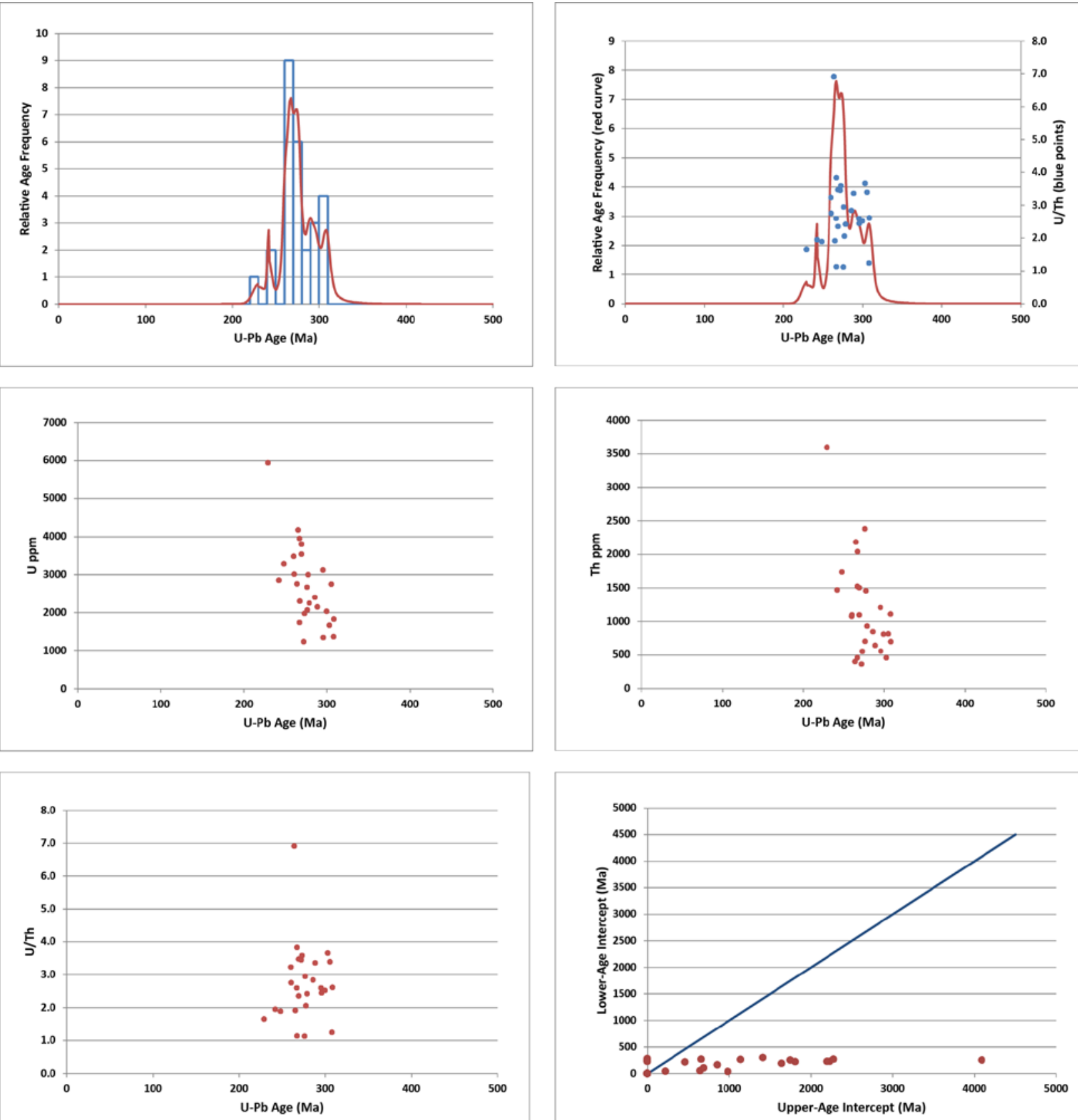
2013ET295 - Felsic Metavolcanic
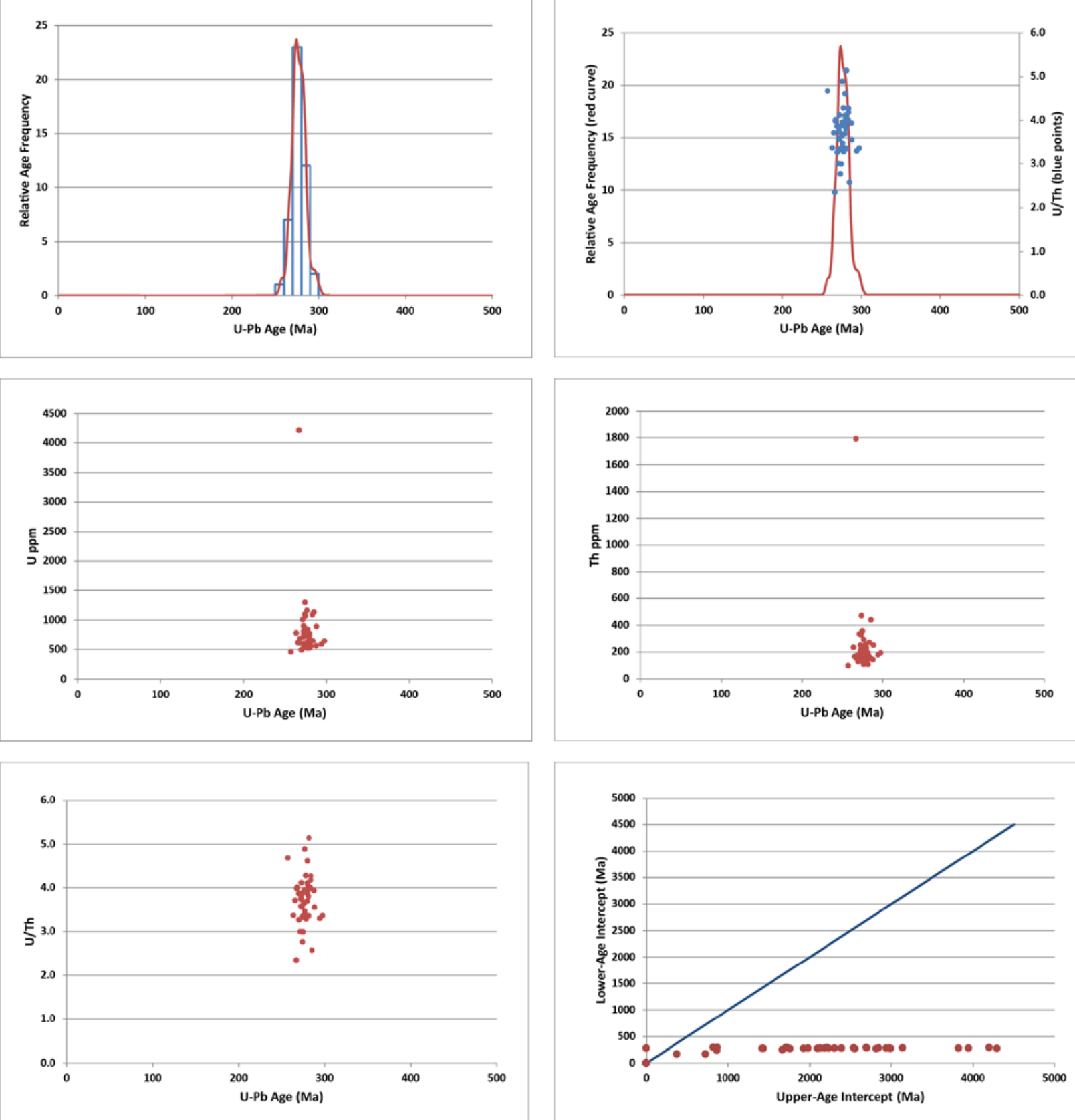